\title{
A legal framework for a data economy in the European Digital Single Market: rights to use data
}

\author{
Herbert Zech*
}

\section{Introduction}

In the Digital Single Market Strategy for Europe $(\mathrm{DSMS})^{1}$ the Commission outlines possible legal approaches to the challenges of digitization. ${ }^{2}$ It explicitly mentions 'ownership' respectively 'rights to use data' as an aspect. ${ }^{3}$ This gives rise to the question of data ownership.

\section{Building of a data economy as part of the strategy for a Digital Single Market}

The DSMS is based on three 'pillars' and pursues three major objectives: ${ }^{4}$ first, a better online access for consumers and businesses to goods and services throughout Europe (in particular better access to digital content, modern and more European copyright); secondly, creating the right conditions for thriving digital networks and services; and, thirdly, making the best possible use of the growth potential of the European digital economy. The third objective shall be reached by three measures: On the one hand the build-up of a data economy, on the other hand the increase in competitiveness through interoperability and standardization and thirdly an inclusive digital society. An important aspect in building a data economy (also referred to as 'data-based economy' in the Commission Staff Working Document ${ }^{5}$ ) is the question of which property-like rights concerning data exist or should exist. This is also explicitely addressed in the DSMS.

\footnotetext{
* Email: lstzech-ius@unibas.ch.

1 European Commission, A Digital Single Market Strategy for Europe, Communication, COM (2015) 192 final, 6 May 2015.

2 Digitization is understood as the growing importance of information technology in every sector of the economy and all aspects of everyday life. Cf. ibid, 3: 'The global economy is rapidly becoming digital. Information and Communications Technology (ICT) is no longer a specific sector but the foundation of all modern innovative economic systems.'

3 ibid, $14 \mathrm{ff}$.

4 ibid, $3 \mathrm{ff}$.

5 European Commission, 'A Digital Single Market Strategy for EuropeAnalysis and Evidence', Staff Working Document SWD (2015) 100 final, 6 May 2015, 57.

6 European Commission, Communication, above, n 1, 14.
}

\section{Technical background}

The DSMS also addresses basis of the data economy, ie the relevant new technologies and business models: mass data processing (Big Data), cloud services, data-driven science and the Internet of Things. ${ }^{6}$ The Commission Staff Working Document (SWD) additionally points out: 'Data has become a new factor of production, an asset and in some transactions a new currency. ${ }^{7}$ Data became a separate production factor and an economic asset. A key role belongs to the 'transition to a smart industrial system (Industrie 4.0)' ${ }^{8}$ The so-called Industrie 4.0, ie the fourth industrial revolution after mechanization, division of labour and automation, is thus a decisive factor. It is characterized by a widespread, direct networking of 'intelligent' objects via the Internet. ${ }^{9}$ The SWD explicitly highlights that it involves not only industrial production but also agriculture. $^{10}$ In addition to the networking of objects (Internet of Things), the Commission identifies 'digital services such as cloud computing' and 'big data (including data-driven science and geo-spatial data)' as additional aspects driving the transformation process. ${ }^{11}$

\section{Legal aspects}

The DSMS mentions four areas of law as sources relevant to the construction of the data economy: ${ }^{12}$

(I) restrictions on the free movement of personal data (in particular in relation to the physical location of the data), ie data protection law;

7 European Commission, SWD, above, n 5, 59.

8 Ibid, 57.

9 Acatech, 'Securing the Future of German Manufacturing Industry: Recommendations for Implementing the Strategic Initiative INDUSTRIE 4.0', Final Report of the Industrie 4.0 Working Group (2013), 17. Available at http://www.acatech.de/fileadmin/user_upload/ Baumstruktur_nach_Website/Acatech/root/de/Material_fuer_ Sonderseiten/Industrie_4.0/Final_report_Industrie_4.0_accessible.pdf (accessed 1 September 2015). Cf U Sendler (ed.), Industrie 4.0, 2013; P Bräutigam and T Klindt, 'Industrie 4.0, das Internet der Dinge und das Recht' (2015) Neue Juristische Wochenschrift 1137.

10 European Commission, SWD, above, n 5, 57.

11 Ibid, 58.

12 European Commission, Communication, above, n 1, $14 \mathrm{ff}$. 
(II) copyright provisions whose inconsistent implementation is seen as an obstacle;

(III) rights to use data (examined in more detail below); and

(IV) the allocation of liability in relation to aspects other than personal data.

In addition, the initiative 'Free flow of data' has been announced. This initiative will address restrictions on the free movement of data for reasons other than the protection of personal data and unjustified restrictions regarding the physical location of storage and processing of data, whereas amongst other things the 'emerging issues of ownership' are explicitly addressed again. ${ }^{13}$

It should be noted that some important areas of law for a data economy are not mentioned, specifically contract and competition law (unfair competition law and law of competition).

\section{Building a data economy as a legislative task}

Possible rights to use data are to be seen as part of a comprehensive legal framework for a data economy. To illustrate that, I will explain how a data economy actually works or could work. Next, typical situations where data are treated as goods are characterised from a legal perspective. Finally, the relevant areas of law and their respective functions are identified.

\section{The value chain for Big Data issues: production, collection and analysis of data}

The development of information technology has greatly lowered the cost, size and weight of sensors, memory elements, networks, computers and control elements. Therefore data can be, so to speak, incidentally stored, transmitted and analysed in view of generating revenue. The impact of these technologies can be three main aspects can be distinguished. First, conventional physical goods come with data references. For example, simple cars become 'driving computers'. This often involves the addition of 'smart' technologies, and affects a broad range of commercial objects and everyday items, such as vehicles, manufacturing machinery, agricultural machinery, mobile phones, home furnishings and even

13 Ibid, 15.

14 Term based on M Becker, personal communication, September 2015.

15 V Mayer-Schönberger and K Cukier, Big Data-A Revolution That Will Transform How We Live, Work and Think (John Murray 2013), 5; W Dorschel and J Dorschel, 'Chapter Title', in J Dorschel (ed), Praxishandbuch Big Data, Wirtschaft_Recht_Technik (Springer Gabler 2015) 1, 6 ff, 9.

16 Indirectly derived innovations can be inventions (technical innovations), copyright protected works (cf A Wiebe, 'Der Schutz von Datenbanken - clothing (wearables). Secondly, conventional physical goods are increasingly replaced by data (digital content rather than traditional media), for example in the form of e-books, e-papers or streaming services. This in turn has an impact copyright (and the first pillar of the DSMS). Thirdly, data is also traded as a novel good in its own right. Data economy not only means datadriven or data-controlled economy (since the control of economic processes through data has existed for a long time and has acquired a new quality through networking), but also an economy with data itself as a type of good.

Not only processed data or information, but also socalled 'raw' or 'machine data' ${ }^{14}$ is traded as economic goods. Such data is automatically recorded, and by analysing large quantities of such data new insights can be gained. Analysing raw data represents the core of socalled Big Data applications. Raw data becomes a 'commodity ${ }^{15}$ which is traded in a data economy. As a result, the question of transferable rights of use becomes important. The value chain of these applications can be divided into the production of data (by operation of sensors, either deliberately or incidentally); the collection of data; the analysis by statistical evaluation and, only as an intermediate result, innovations based on the resulting insights. ${ }^{16}$

Rights of use, or exclusive rights, intervene at different levels according to their conditions and their effects. Classic IP law (especially patent law, but also copyright) operates only at the level of the innovation process (more precisely at the stage of invention, not upstream at the conception stage or downstream at the level of the product). ${ }^{17}$ The core question in the debate on rights to use data is therefore whether exclusive legal protection should intervene at the stage of data production prior to any innovation.

\section{Companies and consumers as parts of the value chain}

There are two potential actors in a data economy: companies and consumers. Although the State plays an important role, especially in data protection law, its role shall not be further addressed in this article. Concerning public information, special public law provisions exist, namely the rules on freedom of

ungeliebtes Stiefkind des Immaterialgüterrechts' (2014) volume(issue) Computer und Recht 1 para 9) or other innovations. The term innovation is used in the broader sense comprising the whole process leading from ideas to inventions to new products/innovations in the narrower sense.

17 H Zech, 'Life Sciences and Intellectual Property: Technology Law Put to the Test' (2015) 7 ZGE/IPJ Zeitschrift für Geistiges Eigentum/Intellectual Property Journal, 1, 3. 
information (access to information) and further processing of information. ${ }^{18}$ The relationship between these rules and potential private-sector rights to use data may, however, pose special problems.

Companies as well as consumers can appear as concerned parties, ie as party to which the data relates. If the party is an individual, they are the 'data subject' within the meaning of Article 4(1) of the General Data Protection Regulation proposal. ${ }^{19}$ In this case the data is 'personal data'. Companies and consumers can also be producers of data. With the proliferation of complex devices consumers become increasingly important as data producers, whether as operators of 'smart cars' or carriers of 'wearables'. Within the Industrie 4.0 companies become data producers, even if their corporate purpose is different altogether.

Data is regularly analysed only at business level, regardless of the source of the data. In addition to determining whether the data is personal in nature (in which case data protection law would be applicable), intermediary data trade relies on the distinction between consumer-generated and company-generated data.

In what follows I will address the question whether the source of data affects the legal scope of rights to use the data.

\section{Creation and regulation of data markets}

The role of law in data markets can be examined from two different perspectives, depending on the function of law. On the one hand, law may restrict free data traffic. Due to the primary objective of the European Union to eliminate trade barriers, this perspective prevails for the DSMS. ${ }^{21}$ Restrictions on data traffic derive from regulation, in particular data protection law, but also from intellectual property rights. On the other hand, law enables data traffic in the first place. This is true of regulatory law which creates clear 'rules of the game', but also of contract law, competition law and intellectual property rights law which create markets for incorporeal assets by allocating transferable rights. Thus the main focus of this article is not to keep the legal framework for a data economy as slim as possible, but to create an appropriate legal framework for a data

18 See A Wiebe and E Ahnefeld, 'Zugang zu und Verwertung von Informationen der —ffentlichen Hand' (2015) Computer und Recht 127 and 199.

19 Proposal for a Regulation of the European Parliament and of the Council on the protection of individuals with regard to the processing of personal data and on the free movement of such data (General Data Protection Regulation proposal), COM (2012) 11 final, 25 January 2012.

20 About rights to use data in 'smart cars', see G Hornung and T Goeble, 'Article Title' (2015) Computer und Recht 265.

21 European legislation concerning exclusive rights usually refers to Treaty on the Functioning of the European Union (Consolidated Version), 2008 OJ economy, and in particular for a functioning data market. As I will show later, there are good reasons why such a framework includes rights to use data.

The essential aspects of the legal framework for a data economy mentioned by the DSMS are data protection law, copyright (if the sui generis right for the maker of a database is considered as a part of copyright since the individuality requirement for the protection as a work is usually not met), rights to use data (for a definition see the next section) and liability law. On the one hand, the task of the law is to ensure that data markets exist (since the exchange and use of data are desirable); on the other hand, its task is also to minimize regulatory risks for market participants (especially consumers). Contract law, consumer protection law and competition law need to be mentioned in this context. In particular, the relationship between companies and consumers is not just about protecting consumers as data subjects in terms of data protection law, but it is also about fairness in data transactions, whether personal or corporate data.

\section{What is the meaning of 'data ownership' or 'rights to use data'?}

Before delving into rights to use data-whether existing rights or those yet to be created-we must define the term. This section clarifies the term 'data' and deals with the concept of right to use.

\section{What is data? Data as an object of rights}

In its simplest meaning, the term data can be defined as machine-readable encoded information. ${ }^{22}$ The definition of data as a legal object or as an economic good is, however, key to answering the question whether there should be rights to data at all. ${ }^{23}$

A distinction can be made on the level of meaning (semantic information), such is the case with personal data defined as information relating to a person (Article 4(2) of the General Data Protection Regulation proposal $\left.{ }^{24}\right)$. Know-how is also considered to be semantic information, when defined by its meaning.

C 115/47, Art 114 (TFEU) as the basis of competence. Also data protection aims at eliminating trade barriers. The DSMS, COM (2015) 192 final, 6 May 2015, 14, argues from this angle too, but also states that there is a 'lack of clarity over rights to use data' which not only concerns their function as a market barrier but also as an instrument for the creation of markets.

22 H Zech, Information als Schutzgegenstand (Mohr Siebeck 2012), 32.

23 Like information data as an object of rights can be defined on three different levels: meaning, signs and physical carrier; H Zech, 'Information as Property' (2015) 6 Journal of Intellectual Property, Information Technology and E-Commerce Law 3, 192, 194.

24 General Data Protection Regulation proposal, above, n 19. 
The term 'data' can also be defined on the level of signs (syntactic information), regardless of its meaning. As a legal object, sequences of 'zeros' and 'ones' would be protected, either as a file or as a data stream. This distinction is comparable to other syntactic representations of information, such as text (defined by its symbols rather than meaning).

\section{Rights to use data}

Rights to use data or property-like rights concerning data ('ownership') are to be understood as the allocation of data by means or at least along the lines of exclusive rights. Ownership rights as comprehensive rights to tangible property and 'classic' intellectual property rights such as patent law and copyright law serve as exemplary models. They are supplemented by less clearly contoured neighbouring rights, as well as unfair competition law.

In addition to a clear definition of the subject matter, allocation of economic value is another important criterion allowing us to determine the existence of a property-like allocation of legal powers over an object or good. For example, interferences with legal claims result not only in claims for damages, but also give rise to disgorgement of profits ${ }^{25}$ based on unjust enrichment and assumed agency and the transferability of rights (which is not necessary for the allocation of economic value where licensability suffices). There is a hierarchical relationship between transferability and allocation of economic value, since transferability of rights requires allocation of economic value. However, the latter does not presuppose the former. Rather, it is sufficient if the right confers commercial use in other ways than by transferring them completely. At the very least it is required that the subject matter is transferable de facto, so that the assigned powers may actually be exercised by a person other than the right-holder, which for example is also true of certain personality aspects like one's own image (defined semantically).

25 See T Helms, Gewinnherausgabe als haftungsrechtliches Problem (Mohr Siebeck 2007), 25 ff; A Peukert, Güterzuordnung als Rechtsprinzip (Mohr Siebeck 2008), 402 ff, 512; cf R Ellger, Bereicherung durch Eingriff (Mohr Siebeck 2002), 890 ff; F Hofmann, 'Gewinnherausgabe bei

Vertragsverletzungen' (2013) 213 Archiv für die civilistische Praxis 469; JF Hoffmann, 'Zum vermögensrechtlichen Schutz absoluter und relativer Rechtspositionen an der Schnittstelle zum Immaterialgüterrecht' (2014) Juristische Ausbildung 71.

26 General Data Protection Regulation proposal, above, n 19.

27 Charter of Fundamental Rights of the European Union, 2000/C 364/01.

28 TFEU, above, $\mathrm{n} 21$

29 B Buchner, Informationelle Selbstbestimmung im Privatrecht (Mohr Siebeck 2006), 202 ff; W Kilian, 'Wie der Staat unsere Daten schützen kann', Frankfurter Allgemeine Zeitung (4 July 2014), available at http:// www.faz.net/aktuell/wirtschaft/netzwirtschaft/vom-recht-auf-die-eige nen-daten-13025525.html (accessed 10 October 2015); cf K v Lewinski,
The question as to under what conditions personal rights may be regarded as assignable rights is important for data protection which in its original function is a personal right closely connected with the right to privacy.

\section{Data protection as a right to use data?}

Data protection legislation has been harmonised at the EU level, and data protection law is due to be fully harmonized by the proposed General Data Protection Regulation. ${ }^{26}$ The regulatory purpose of data protection law, as is clarified in the first recital of the proposed General Data Protection Regulation, is the protection of individuals with regard to the processing of personal data. The formulation of the relevant fundamental rights guaranteed in Article 8(1) EU Charter of Fundamental Rights ${ }^{27}$ and Article 16(1) Treaty on the Functioning of the European Union (TFEU) ${ }^{28}$ is misleading with regard to the wording: 'Everyone has the right to the protection of personal data concerning him or her.' This however does not in particular mean the protection of data, but rather the protection of the person against any danger caused by the use of their personal data.

However, some scholars argue that current data privacy protection law could be further developed into a data property right, meaning that its function is thus expanded from a mere protection of personality to a participation in the economic value of personal data. ${ }^{29}$ When developing further data protection into rights to use data of the persons concerned (data subjects), several problems arise. On the one hand, data protection law does not allocate all personal data exclusively to the person concerned. Currently there is no such thing as 'right to one's own data', ie no personal right to any information concerning oneself, as it is recognized in the relation between individuals and the State in the form of the fundamental right to informational selfdetermination. ${ }^{30}$ Data protection law protects the

Die Matrix des Datenschutzes (Mohr Siebeck 2014), 50 ff. R Schwartmann and C-H Hentsch, 'Eigentum an Daten - das Urheberrecht als Pate für ein Datenverwertungsrecht' (2015) RDV Recht der Datenverarbeitung 221. For the US discussion regarding data protection as "quasi IP" see L Henry Scholz, 'Privacy as QuasiProperty' (2015) Iowa Law Review, Forthcoming'; S Balganesh, 'QuasiProperty: Like, But Not Quite Property' (2012) 160 University of Pennsylvania Law Review 1889; P Samuelson, 'Privacy as Intellectual Property' (1999) 52 Stan. L. Rev. 1125

30 D Klippel, 'Deliktsrechtliche Probleme des Datenschutzes' (1983) BB, 407 (408); S Simitis, 'Die informationelle Selbstbestimmung Grundbedingung einer verfassungskonformen Informationsordnung' (1984) NJW 398, 400; H Ehmann, 'Informationsschutz und Informationsverkehr im Zivilrecht' (1988) 188 AcP 230, 266 ff; C Hohmann-Dennhardt, 'Wem gehören personenbezogene Daten?' (2009) DSB 13, 14 . 
personality only against certain forms of data processing. In principle, contracts about personality rigts are permissible, although only with obligatory effect. ${ }^{31}$ This raises the central question of whether a mere reference to personality can actually a sufficient justification for the allocation of transferable exclusive rights in dealing with one's own personal data.

\section{Absence of right to one's own data}

Data protection law does not allocate comprehensive rights of use over one's own personal information; it only addresses certain forms of data processing, which potentially entail a serious interference with personal rights. In relationships between private persons, Article 6(1)(f) of the General Data Protection Regulation proposal plays a pivotal role. It shows that data protection, like many personal rights, is a law open to interpretation (ie interventions can be justified by balancing conflicting interests).

A complete allocation of one's own data (semantically defined by reference to their own personality) would be inconsistent with constitutionally protected freedom of expression and information. The German Federal Supreme Court summarizes this succinctly in the Spickmich.de judgement:

However, the individual has no absolute, unrestricted control over its data; because it develops its personality within the social community where information, even if it is personal, is a part of social reality which cannot be exclusively assigned to the person concerned alone. ${ }^{32}$

\section{Property-like allocation of economic value}

In terms of legal consequences, the question is whether to assign to the person concerned, a position procured by current data protection law, with the allocation of economic value (which under German doctrine is among other things important for claiming profits in case of a

31 A Ohly, 'Volenti non fit inuria-Die Einwilligung im Privatrecht (Mohr Siebeck, 2002), 141 ff, 165 ff, 259 ff; H Beverley-Smith, A Ohly and A Lucas-Schloetter, Privacy, Property and Personality (Cambridge University Press 2005), 94 ff; F Hofmann, 'The Economic Part of the Right to Personality as an Intellectual Property Law? - A Comparison between English and German Law' (2010) 2 Zeitschrift für Geistige Eigentum/Intellectual Property Journal 1.

32 BGHZ 181, 328 = NJW 2009, 2888, "www.spickmich.de". In original: Allerdings hat der Einzelne keine absolute, uneingeschränkte Herrschaft über 'seine' Daten; denn er entfaltet seine Persönlichkeit innerhalb der sozialen Gemeinschaft. In dieser stellt die Information, auch soweit sie personenbezogen ist, einen Teil der sozialen Realität dar, der nicht ausschließlich dem Betroffenen allein zugeordnet werden kann.

33 For contracts on personal rights Ohly, above, n 30, 165 ff, 259 ff; Beverley-Smith et al, above, n 30, $129 \mathrm{ff}$, with further references.

34 The consent regulated in German Federal Data Protection Act, Bundesdatenschutgesetz (BDSG), s 4(a) is in general freely revocable and violation). The personal right of the protected person is certainly not transferable (unlike the right of publicity recognized in the USA). However, since with the consent of the person concerned illegal data processing becomes legal according to Article 6(1)(a) of the proposed General Data Protection Regulation, there is a possibility of giving such consent and by doing so entering into a contractual obligation within the limits of contract control. Thus the concerned party can use his/her position similarly to other personal rights ('personality licensing'). ${ }^{33}$ However, the ability to conclude binding agreements is severely limited by the free revocability of consent, ${ }^{34}$ which shall also be codified in Article 7(3)(1) of the General Data Protection Regulation proposal. Problems might also arise if a consent given in return for services would be deemed non-voluntary or imbalanced.

Despite the option of revoking consent, the protected person may exploit protected personal data by granting consent: for instance, the revocation of a given consent pursuant to Article 7(3)(2) of the General Data Protection Regulation proposal deploys no retroactivity. Personal data defined by its semantic content is inseparably connected to the protected person, but it can be detachable from that person just as his/her picture is, because it can be processed without that persons's continued involvement. Data protection arguably works as an allocation of economic value. ${ }^{35}$ However, there is is no clear cut property like allocation of data, resulting from data protection law but rather a personality right open to balancing all interests concerned. One can at best speak of a 'right to the protection of personal data' (ie open to balancing with conflicting interests) but not of a property-like 'right to one's own data. ${ }^{36}$

\section{Justification}

The background of the discussion about data protection as a property like right is a justification issue. Is the mere fact that an economic good is semanticly related

the possibility of revocation cannot be waived effectively in advance, $\mathrm{P}$ Gola and R Schomerus, BDSG - Bundesdatenschutzgesetz

Kommentar (12th edn CH Beck 2015) s 4 para 38; T Herbst, 'Die Widerruflichkeit der Einwilligung in die Datenverarbeitung bei medizinischer Forschung' (2009) MedR 149, 150. This applies at least in cases where the person concerned realizes the consequences of the data processing only after granting such consent, S Simitis, 'Commentary on BDSG', s 4 in P Gola and R Schomerus, BDSG - Bundesdatenschutzgesetz Kommentar (8th edn CH Beck 2014) s 4 para 94.

35 W Kilian, 'Personal Data: The Impact of Emerging Trends in the Information Society - How the marketability of personal data should affect the concept of data protection law' (2012) CRi 169, 172; Zech, above, n 22, $219 \mathrm{ff}$.

36 See eg KH Ladeur, 'Datenschutz - vom Abwehrrecht zur planerischen Optimierung von Wissensnetzwerken' (2000) DuD 12, 18: 'not a personal right but part of a of a new kind of property right' ('nicht dem Persönlichkeitsrecht zugeordnet ..., sondern als Bestandteil eines neuartigen Eigentumsrechts.'). 
to a person reason enough that the value should belong to that person? From a Lockean perspective mixing a good with one's own personality is sufficient. Copyright can be justified by the traces of personality in the work. However, the work is also created by the author which provides a crucial economic rationale for copyright protection. Personal data are linked to a person by their meaning but are not created by that person.

The question of whether the protection of personality justifies an economic allocation cannot be discussed in more detail here. However, it seems that with the current configuration of many personal rights, with the allocation of economic value on the side of legal consequences, and on the side of legal facts the maintenance of prerequisites that are open to consideration, the limit of an allowable approach on property rights has been reached. The most weighty argument may be that real property-like rights can be withdrawn even against the will of the entitled legal entity, for example in the event of foreclosures. ${ }^{37}$ This must not be possible with personal rights, at least if the right-holder her- or himself has not exploited them (similarly to copyright). Even contracts should not automatically render data protection ineffective. The validity of a consent to data processing given in consideration for services free of charge has to be determined on a case to case basis. When consent is given as a contractual term which has not been individually negotiated it may be an unfair term depending on the circumstances.

\section{Protection of trade secrets}

With the proposal of a directive on the protection of undisclosed know-how and business information (trade secrets), ${ }^{38}$ the protection of trade secrets is the subject of European harmonization efforts. Although data may qualify as trade secrets, the protection does not lead to a real data use right. Especially with Big Data matters this leads to problems.

\section{Data as a protected secret}

One of data protection requirements is that the data constitute a trade secret. This requirement automatically

37 Peukert, above, n 24, $534 \mathrm{ff}$.

38 Proposal for a directive of the European Parliament and of the council on the protection of undisclosed know-how and business information (trade secrets) against their unlawful acquisition, use and disclosure, COM (2013) 813 final, 28 November 2013.

39 For the protection under criminal law as set out in German Penal Code, s 202(a), see below. In addition, the protection of technical measures under German Copyright Act, s 95(a) can be considered, provided that there is a protected work or any other object protected by German Copyright Act (database protected as work or by sui generis right). In any case, data are not such a protected object, see below.

40 Draft Directive, COM (2013) 813 final, 28 November 2013, Art 2(1). Cf Agreement on Trade-Related Aspects of Intellectual Property Rights applies to collected data, provided that it is business-related (where storage as part of business operation is a sufficient justification), that it is non-obvious and that there is an expressed or at least recognizable intention to keep secrecy and an economic interest in the confidentiality by the business holder. All these conditions can also be met if the manufacturer of a complex machine keeps the data collected by the machine secret in respect of his/her clients. ${ }^{39}$

Where trade secrets are understood as 'information', 40 there is a definition at the semantic level (as in data protection). However, it is not necessarily information about the protected business (business-related information); but rather any kind of information. The only precondition is that the company has the information legitimately under its control ('lawfully within their control', Article 39(2) of the Agreement on Trade-Related Aspects of Intellectual Property Rights (TRIPS); cf Article 2(1)(c) of the draft Directive) ${ }^{41}$ It is sufficient that the business has control over business-known secrets. Article 3(2)(a) and Article 11(2)(e) of the draft Directive (and recital 6) explicitly mention 'electronic files containing or implementing the trade secret' (syntactic information).

According to Article 2(1)(b) of the draft Directive a trade secret must have a commercial value because of its secrecy. According to recital 8, the definition of trade secrets should not include any 'trivial information'. In case of individual measurement data it could be argued that this does not yet have any commercial value but is nonetheless trivial. This shows that recital 8 is based on false premises: with Big Data, trivial information can have economic value when there is enough trivial information put together and analysed. The existence of a market for such data is likely to disprove its worthlessness. Even raw data has value which, under certain circumstances, just happens to be very low. ${ }^{42}$ Since the value of data does not have to exceed any minimum quantitative threshold, the requirement of a commercial value pursuant to Article 2(1)(b) of the draft Directive should not be any problem and can be fulfilled. This, of course, also is true for the requirement of commercial interest under German law, for example to manufacturers of complex machines.

(adopted 15 April 1994, entered into force 1 January 1995), 1869 UNTS 299, Art 39(1) (TRIPS): 'information'.

41 In the Draft Directive it reads 'trade secret holder', cf Draft Directive, above, n 39, Arts 3, 9, 11 and 13. According to ibid, Art 2(1)(c), the definition of trade secret includes the idea that the protected information is 'subject to reasonable steps under the circumstances, by the person lawfully in control of the information, to keep it secret'. Ibid, Art 10(1) requires a legitimate holder as well. The 'legitimate holder' is also mentioned in ibid, recitals 3, 5, 6, 13-15 and 18 .

42 K Neumann, 'Es gibt kein belangloses Datum mehr!' (2011) DANA Datenschutz Nachrichten 44: 'There is no trivial datum anymore!' ('Es gibt kein belangloses Datum mehr!'). 


\section{Protective effect}

Although protection of corporate secrets is considered to fall at least in part into the category of intellectual property, ${ }^{43}$ and although it was incorporated into TRIPS by Article 39, it grants no genuine exclusive right. In particular, protection of corporate secrets depends on the factual existence of a secret, and thus rather resembles the protection of possession. ${ }^{44}$ In addition, the information is not protected against any use, but only against certain attacks on the secret.

With Big Data, the analysis of data by third parties would necessarily imply an infringing disclosure, provided that the third party has no authorized access, for example through the acquisition of data on the basis of a know-how contract. Thus analysing data as a use of secrets that have been obtained by violating secrecy or by commercial espionage, would be included in the protection of corporate secrets. It is appropriate that a repeated measuring remains admissible because the protection does not transfer exclusive powers to the information (incidentally, there are also exclusive rights, allowing the independent re-creation of an object of protection, cf Article 19(2) of the Community Design Regulation ${ }^{45}$ for the unregistered Community design).

The legal position of the protected trade-secret holder has property-like traits, as far as the allocation of economic value is concerned. Although, according to the prevailing opinion, no transferable right results, know-how is at least factually transferable and thus can also be the object of legal transactions and be economically exploited. ${ }^{46}$ Accordingly, an allocation of economic value, ie the possibility of undue enrichment in case of injury, is affirmed. When it comes to information which is detachable from the business, such as data from automated measurements, this is to advocate at least as a framework law.

\section{Protection of trade secrets as an inadequate legal framework}

Protection of trade secrets does not cause an independent legal allocation: it merely amplifies the existing de facto exclusivity of data by protective rights. Therefore

43 See also A Ohly, 'Der Geheimnisschutz im deutschen Recht: heutiger Stand und Perspektiven' (2014) GRUR 1, 3 ff.

44 M Dorner, Know-how-Schutz im Umbruch (Carl Heymanns 2013), 111; M Dorner, 'Big Data und "Dateneigentum" - Grundfragen des modernen Daten- und Informationshandels' (2014) CR 617, 619; A Ohly, above, n 43, 8; Zech, above, n 22, 241.

45 Council Regulation (EC) No 6/2002 of 12 December 2001 on Community designs, OJ L 3/1, 5 January 2002.

46 Cf Dorner, above, n 44, 83 ff, 214 ff; Zech, above, n 22, 234 ff, each with further references.

47 German BT-Drs 17/14362v 10 July 2013, GesE des Bundesrates, Entwurf eines Gesetzes zur Strafbarkeit der Datenhehlerei, 7; RefE des one can indeed refer to the protection of corporate secrets as legal assignment to those parties who have a de facto exclusive access to the data (recording or storing party). However, any problems with the existing factual situation tend to be reinforced thereby.

In Industrie 4.0 matters the allocation by the protection of trade secrets leads to problems: usually, there are several businesses involved, whose respective secrets are difficult to distinguish. From the point of view of the user of complex manufacturing machines any generated data are the user's trade secrets. From the point of view of the manufacturer(s) of the machines, that may by design exclude the users from access, it is rather assumed to be their secrets. If several machines work together or are linked, which is likely to be the rule, the allocation becomes even more difficult.

The spatial expansion of the business sphere, ie the impossibility to demarcate it by physical gates is an inevitable consequence of information technologies (IT) (just think of cloud computing). What actually creates problems is the delimitation of one operating sphere to the other. A lack of transparency is currently one of the main problems encountered in IT. This is true not only for consumers but also for companies. And the problem is further exacerbated by the protection of corporate secrets. This gives reason for a cautious application of trade secret protection to Big Data matters. The specific criminal offences of the Penal Code, in particular ss 202(a) ff of the German Criminal Code (which are to be complemented by an offence of 'data receiving') should protect against the specific risks of IT for secrets. ${ }^{47}$

\section{Sui generis right for the maker of a database}

By introducing sui generis protection for the maker of a database according to Articles $7 \mathrm{ff}$ of Directive 96/9/ EC, ${ }^{48}$ the European legislature addressed the problem of data as an economic good. Subject matter, however, is not the data itself, but the database or the investment in the creation of a database. Unlike classical intellectual property rights this right no longer protects a creation

Bundesministeriums der Justiz und für Verbraucherschutz v. 15 May 2015, Entwurf eines Gesetzes zur Einführung einer Speicherpflicht und einer Höchstspeicherfrist für Verkehrsdaten, 19.

48 Directive 96/9/EC of the European Parliament and of the Council of 11 March 1996 on the legal protection of databases, OJ L 077/22, 27 March 1996. This sui generis right supplements the pre-existing copyright protection of databases (German Copyright Act, s 4-II). The requirement of a substantial investment (German Copyright Act, s 87(a)-I) replaces the requirements for copyright protection of an personal intellectual creation ('persönliche geistige Schöpfung') involving a selection or an arrangement. The exclusive right is assigned to the investor (maker of a database, German Copyright Act, s 87(a)-II). 
of the human mind, but the result of an investment. ${ }^{49}$ Case law has shaped the right for the maker of a database in a way that it generally does not encompass the use of data in Big Data issues, at least not to the data generator. ${ }^{50}$ This is mainly due to the understanding of significant investment as a condition for protection which is reflected in the scope of protection.

\section{Subject matter: database}

In the case of automatically collected data no human intellectual achievement is present. Therefore, in accordance with Article 3(1) of Directive 96/9/EC, no database work protected by copyright exists. By contrast, the outcome of automated measurements and recordings to a database usually qualifies as a database (Article 1(2) Directive 96/9/EC).

\section{Collection}

Especially in the case of automated measurements not only a useless collection of data is produced, but also a structured arrangement of data. ${ }^{51}$ The files to be transferred, containing the data of individual devices and a fortiori files created by merging data from multiple devices, are in any case to be qualified as a collection.

\section{Of independent works, data or other materials}

Independent materials are the data as single measurements, ie differentiated on the semantic level. The legislator's decision not to base the subject matter on individual

49 A Steinbeck, 'Immaterialgüterrechte und Informationsinteresse' (2010) KSzW 223, 224: Not just the creator of an intellectual effort, but anyone supporting the creation and/or dissemination of information by contributing organizational effort and financial investment has a general interest in early exclusive use and exploitation of information. ('Nicht nur der Schöpfer einer geistigen Leistung, sondern auch derjenige, der mit organisatorischem Einsatz und finanziellen Investitionen dazu beiträgt, dass Informationen generiert und/oder verbreitet werden, hat regelmäßig ein Interesse daran, diese Informationen zunächst ausschließlich selbst zu nutzen und auszuwerten.').

50 C Zieger and N Smirra, 'Fallstricke bei Big Data-Anwendungen Rechtliche Gesichtspunkte bei der Analyse fremder Datenbestände' (2013) MultiMedia und Recht 418, 420 ("'relevant violation" as an "exception"'; in original: “"relevante Verletzungen" als "Ausnahme”). Wiebe, above, n 16, $1 \mathrm{ff}$, however shows that there are many Big Data situations without automated measurements and that the sui generis right is highly relevant for Big Data situations (although not for the protection of the data producer). Similarly, T Ehmann, 'Big Data auf unsicherer Grundlage - was ist "wesentlich" beim Investitionsschutz für Datenbanken?' (2014) Kommunikation \& Recht 394, 395:

The case law has begun to shape the new protective right. Nevertheless, the impact of the database producer right on the legal practice still lags behind the economic significance of data as an asset.

Die ... ergangenen höchstrichterlichen Entscheidungen haben dem neuen Schutzrecht inzwischen erste Konturen verliehen. Dennoch data is likely to be due to the fact that the legislator wanted to keep the (semantic) information in the public domain. ${ }^{52}$ An exclusive right to the individual semantic information (as was discussed, for example, for the protection of daily updated news ${ }^{53}$ cannot be justified. It would have been easier, to base protection on the individual data and to distinguish them on the syntactic level.

The independence of materials, required to qualify a collection as a database, is not a problem. Rather, it is almost a hallmark of Big Data where a large amount of data is not immediately intended for a specific use but optionally analysed later. Based on the Fixtures Marketing jurisprudence, ${ }^{54}$ independence presupposes that the individual elements can be used on their own. This is true even of the most insignificant piece of data, to the extent that it is a well-structured information unit, ${ }^{55}$ ie a unit with semantic content. ${ }^{56}$ With the formulation 'independent works, data or other materials' ('Daten oder andere unabhängige Elemente', data or other independent elements) the law assumes that at least semantically determined data is automatically independent.

If the criterion of independence is understood as independent usability the concept of goods comes into play, ie not only the database, but also the single data or element should represent independent goods. This demonstrates the classic understanding of data use underlying the regulation: collecting and processing go hand in hand and as a result provide a collection of data easily perceivable by users which therefore are usable data. The Big Data paradigm, however, is the exact opposite: even the most insignificant raw data already represent goods that can only be used by subsequent analysis. ${ }^{57}$

hinkt die Bedeutung des Datenbankherstellerrechts in der Rechtspraxis der wirtschaftlichen Bedeutung von Daten als Wirtschaftsgut hinterher. It could be argued that the importance in legal practice lags behind precisely because of the contouring, in particular due to ECJ, The British Horseracing Board and Others, C-203/02, ECLI:EU:C:2004:695.

51 Wiebe, above, n 16, 2.

52 D Thum and K Hermes, in A-A Wandtke and W Bullinger (eds), UrhR Urheberrecht (4th edn CH Beck 2014), s 87(a) para 26; Ehmann, above, n 50, 395: no 'monopolization of (important) information' (keine 'Monopolisierung von (wichtigen) Informationen'). A Wiebe, in G Spindler and F Schuster (eds), Recht der elektronischen Medien (3rd edn CH Beck 2015, s 87(a) para 1.

53 See also H Prantl, Die journalistische Information zwischen Ausschlussrecht und Gemeinfreiheit (Gieseking 1983), $36 \mathrm{ff}$.

54 Fixtures Marketing I, C-338/02, ECLI:EU:C:2004:696; Fixtures Marketing II, C-444/02, ECLI:EU:C:2004:697; Fixtures Marketing III, C-46/02, ECLI:EU:C:2004:694.

55 Thum and Hermes, supra note 50, s 87(a) para 13.

56 To that effect, see also T Dreier, in T Dreier and G Schulze, Urheberrechtsgesetz Kommentar (5th edn, CH Beck, 2015) s 87(a) para 6.

57 Neumann, above, $\mathrm{n} 42$, 44: 'There is no trivial datum anymore!' ('Es gibt kein belangloses Datum mehr!'). 


\section{Systematic or methodical arrangement}

In order to use individual data it is vital that databases are structured in systematic or methodical order within the data collection. This minor problem is solved if the individual data is filed in a way that it can be retrieved. ${ }^{58}$ Thus, to meet this criterion, data has to be compiled preserving its semantic value. It is, however, extremely unlikely that a collection of data is arranged in a way that the entire collection becomes unusable and thus the requirement of a systematic or methodical arrangement becomes a 'de minimis criterion'. 59

\section{Protection requirement of substantial investment}

As investment represents a criterion, the sui generis protection is quite similar to unfair competition law, although it is not equally flexible. ${ }^{60}$ The main reason why sui generis protection did not have any significant impact on Big Data applications might be that the Court of Justice of the European Union (CJEU) in its decisions BHB/Hill and Fixtures Marketing I-III established a limitation to investments in existing data. ${ }^{61}$ Thus, data producers cannot be a legal entity. Although narrowing down the wide spectrum of criteria for protection rights, it is not comprehensible that investments in data production are excluded. ${ }^{62}$ The production of data could have easily been interpreted as acquisition.

The question whether side products of entrepreneurial activity ('spin offs') can at all represent the subject of necessary investment gives rise to a new problem. ${ }^{63}$ It is a substantial characteristic of Industrie 4.0 matters that the data is created incidentally. In its Autobahnmaut (highway toll) decision ${ }^{64}$ the German Federal Court of Justice had to judge a matter in which the database can only be qualified as a side product and affirmed a substantial investment in the acquisition of data.

Irrespective of whether side products of entrepreneurial activity are subject to the regulations, it is rather

58 Dreier, above, n 56, s 87(a) para 7; Thum and Hermes, above, n 52, s 87(a) para 21; A Auer-Reinsdorff, 'Schutz von Datenbanken und Datenbankwerken', in I Conrad and M Grützmacher (eds), Recht der Daten und Datenbanken im Unternehmen (Otto Schmidt 2014) 205, 213 ff.

59 Thum and Hermes, above, n 52, s 87(a) para 24.

60 Ehmann, above, n 50, 399; cf M Leistner, in O Teplitzky, K-N Peifer and M Leistner, UWG Gesetz gegen den Unlauteren Wettbewerb GroÔkommentar (2nd edn 2013), s 4(9) paras 84, 131.

61 The British Horseracing Board and Others, C-203/02, ECLI:EU:C:2004:695; Fixtures Marketing I, above, n 54; Fixtures Marketing II, above, n 54; Fixtures Marketing III, above, n 54. See also M Leistner, 'Anmerkung zu EuGH, Urteil v. 9.11.2004 - Rs. C-203/02 The British Horseracing Board ./. William Hill Organization' (2005) JuristenZeitung 408, 409; M Lehmann, 'Abgrenzung der Schutzgüter im Zusammenhang mit Daten', in Conrad and Grützmacher, above, n 58, 133, 138 ff; Ehmann, above, n 50, 397 ff; Wiebe, above, n 16, 4. the criterion of substantial investment that does exclude consumers from protection. ${ }^{65}$ With regard to Big Data, this is problematic. As illustrated later the protection for data producers could also be outlined without considering investments (be it in production or in the collection of data) thus including consumers as well.

\section{Effect of protection}

The object of protection (the data collection) is reflected on the level of protective effect. Individual elements are not protected. As a precondition significant parts either in terms of quantity (volume of data) or quality (volume of investment) have to be transferred (extraction, Article 7(2)(a) of Directive 96/9/EC). However, in such cases, the alternative of repeated and systematic uses, which conflict with a normal analysis of the database or unreasonably prejudice the legitimate interests of the maker of the database, can ensure legal protection. ${ }^{66}$ For an extraction it is sufficient that the sum of transfers remains below the materiality threshold but represents a 'repeated and systematic extraction and/or re-utilization of insubstantial parts of the contents of the database implying acts which conflict with a normal exploitation of that database or which unreasonably prejudice the legitimate interests of the maker of the database' (Article 7(5) of Directive 96/9/EC). It suffices if the on-going transfers of insignificant parts are aimed at the eventual transfer of essential parts and in the case of its continuation would result in the fact that a substantial part of the database would be extracted. ${ }^{67}$

\section{A right for the producer of data (data producer right) de lege ferenda}

After analysing the existing legal framework, the question arises whether a real right to use data should be created. What such a data producer right (in the sense of a data producer's right) might look like shall be outlined briefly

62 T Hoeren, 'Anmerkung zum Urteil des EuGH v. 9.11.2004' (2005) MMR 34, 35; M Leistner, 'The protection of databases', in E Derclaye (ed), Research Handbook on the Future of EU Copyright (Edward Elgar 2009), 427, 438; Ehmann, above, n 50, 397: 'According to the natural literal sense gaining new data is a form of procurement as is the purchase of data' ('Nach dem natürlichen Wortsinn ist die Neugewinnung von Daten ebenso eine Form des Beschaffens wie der Erwerb von Daten.')

63 Cf Dreier, above, n 56, s 87(a) para 13; Ehmann, above, n 50, 397 ff.

64 BGH, GRUR 2010, 1004-Autobahnmaut.

65 However, if a benefit is granted for the production of data (use of a data collecting equipment), it would be conceivable to assume an investment of consumers. This investment would have to reach such an extent that an independent economic good results (cf. A Auer-Reinsdorff, 'Schutz von Datenbanken und Datenbankwerken', in Conrad and Grützmacher, above, $\mathrm{n} 56,205,215 \mathrm{ff}$ ), which also applies to raw data.

66 Ibid, 219.

67 BGH, GRUR 2011, 724, $726 \mathrm{ff}$-Zweite Zahnarztmeinung II. 
below. ${ }^{68}$ It shall deal with subject matter, conditions, ownership, scope of protection, exceptions, transferability, relationship with other legal regimes (like data protection) and, last but not least, the question of justification.

A well-defined subject matter would be machinereadable coded information that is defined only by its representative characters (bits) irrespective of its content (data delimited on the syntactic level).

An important protection requirement would be the creation of the data, meaning creation through automated measurement processes, intellectual activity or simple computing power. An additional possibility would be the limitation on measurement processes to completely exclude intellectual creations and separately regulate the problem of digital goods which are produced by processing power (particularly Bitcoins). Comparable current regulations are the protection of photographers under German law (German Copyright Act, s 72) and the protection of phonogram producers (German Copyright Act, s 85; cf Art 2(d) WIPO Performances and Phonograms Treaty, ${ }^{69}$ Art 2(d)).

The ownership of the right would be tied to the economically responsible operator of equipment that generates the data (data producer). ${ }^{70}$ When determining the right-holder by ascertaining the economic responsibility for the processing of goods one can find parallels in the determination of the processor according to $\mathrm{s}$ 950 of the German Civil Code (acquiring property by processing tangible goods) or the person storing data protected under criminal law pursuant to s 202a and s 303a of the German Criminal Code. No distinction should be made between data production by entrepreneurial activities and by consumer behaviour. ${ }^{71}$

The scope of protection would in particular include the use by carrying out statistical analyses, but not the

68 See also H Zech, 'Daten als Wirtschaftsgut - Überlegungen zu einem “Recht des Datenerzeugers"' (2015) Computer und Recht 137, $144 \mathrm{ff}$.

69 WIPO Performances and Phonograms Treaty (WPPT), signed 20 December 1996, entered into force 20 May 2002, 2186 UNTS 203.

70 In a similar sense Becker, above, n 14, who points out, that this also leads to a run in parallel with the protection of trade secrets of the machine operator, who 'usually plays the key role in producing the data' ('idR den größten Anteil an der Datenerzeugung hat').

71 Similar T Hoeren, 'Dateneigentum - Versuch einer Anwendung von $\$$ 303a StGB im Zivilrecht,' MultiMedia und Recht 2013, 486, 487; G Hornung and T Goeble, " "Data Ownership" im vernetzten Automobil' (2015) CR 265 (271). Contra: Becker, above, n 14, who instead recommends a 'right to products without data collection' ('Recht auf datenerhebungsfreie Produkte') for consumers and a right to use data for businesses only. Argument: 'It argues against an allocation decision, if the person entitled in principle has no use for the allocated good, and it is thus allocated only for the purpose of disposal' ('Es spricht gegen eine Zuweisungsentscheidung, wenn der Berechtigte prinzipiell keine Verwendung für das zugewiesene Lebensgut hat, es also nur zum Zwecke der Veräußerung zugewiesen wird.') However, this is also true, eg for patents that are granted a construction office. Hornung and Goeble, 272, see political problems: re-creation of the same data by independent measurement. Here a parallel with the already mentioned Article 19(2) $\mathrm{CDR}^{72}$ is found.

Regarding limitations and exceptions, special attention should be paid to the interest of the public domain. A short term of protection would be appropriate. There also is no need to exclude private parties as possible right holders but it seems reasonable to grant protection only against commercial infringements. Merely allowing for private use as an exemption (as with database producer rights under section 87(c) I para 1 of the German Copyright Act; Article 9(a) Directive 96/9/EC: extraction for private purposes) seems too narrow. A possible wording would be as for example s 11 para 1 of the German Patent Act or s 40 para 1 of the German Design Act (also the Agreement on a Unified Patent Court, Agreement on a Unified Patent Court, signed 19 February 2013, not yet in force, 2013/C 175/01. Art 27(a): acts done privately and for non-commercial purposes). The cumulative requirement of a 'private domain' should possibly be adapted to a world of data that can no longer be spatially delimited. An exemption guaranteeing scientific freedom comparable to Article 9(b) of Directive 96/9/EC seems to be appropriate.

The right should be transferable, since the creation of markets for data is one of the main purposes of the new law. Another main purpose (probably the decisive one) lies in a fair and efficient allocation of the benefits of data use. Within the framework of contract law it would be necessary to consider whether the allocation to the producer should be a role model and accordingly whether the unrequited transfer by stipulating clauses should be restricted. A corresponding consideration will have to be recognized in an offer of better or cheaper services. ${ }^{73}$

The legislator could, for example, be trying to protect traditional (German) vehicle manufacturers of an impending loss of importance that it assigns them the exclusive right of use of anonymized vehicle-related data and the right to sell them on the uprising data marketplaces to third parties. At first sight, such an exclusive assignment would strengthen the position of producers and give them a good position to negotiate pricing. On closer inspection, however, this is less sure when it comes to negotiations with worldwide operating interested parties.

So könnte der Gesetzgeber beispielsweise versucht sein, die traditionellen (deutschen) Kfz-Hersteller dadurch vor einem drohenden Bedeutungsverlust zu schützen, dass er ihnen die exklusive Nutzungsbefugnis an anonymisierten fahrzeugbezogenen Daten und das Recht zuweist, diese auf den entstehenden Datenmarktplätzen an Dritte zu veräußern. Auf den ersten Blick würde eine solche exklusive Zuweisung die Position der Hersteller stärken und ihnen eine gute Verhandlungsposition für die Preisbildung geben. Bei näherem Hinsehen ist dies jedoch weniger sicher, wenn es um Verhandlungen mit weltweit operierenden Interessenten geht.

72 Council Regulation (EC) No 6/2002, above, n 45.

73 Possible contractual models: pricing with two different prices (one without and one with transfer of future rights to the produced data), lease contract (economic operator is the lessee), rental contract (economic operator is the landlord). 
Finally, questions of the interplay with existing rights, particularly data protection law, would have to be clarified. Here, a juxtaposition of various allocation systems would need to be assumed. In any case, the right of the data producer cannot displace the protection of the person concerned.

This leads to the question whether such a right should be created or not. On the one hand, there are significant concerns about the resulting restrictions of the public domain. On the other hand, as in classic intellectual property rights, one could bring forward the argument that incentives are created to generate and to reveal data (and hence, indirectly, to promote innovations that are made possible through the use of data) and that markets for information goods (that otherwise would not be tradable or would only be tradable with higher transaction costs) are created. Another important aspect seems to be that such legal regulation would clearly determine who benefits from the use of data. This would prevent that machines are designed in a way that they are difficult to be read out or that other mechanisms would be created which grant de facto exclusivity. Such a regulation not only saves costs, but would promote a culture of transparency, as 'open data' does. The data producer right would have the same function for 'open data' as the copyright has for 'open source' and 'open content'.

\section{Conclusion}

Data protection and potential rights to use data serve different purposes. Rights to use data can create a functioning market for data and so help building an information economy. It is at least worth considering the establishment of a right of the data producer. Preferably a uniform right should be created, regardless of whether a company or a consumer act as data producers. Due to the economic importance and the enormous implications of such a right a broad social discussion and clarification through legislative action are desirable. 